Niniejsza publikacja jest dostępna na licencji Creative Commons. Uznanie autorstwa-Użycie niekomercyjne-Bez utworów zależnych 3.0 Polska. Pewne prawa zastrzeżone na rzecz autora. Zezwala się na wykorzystanie publikacji zgodnie z licencja - pod warunkiem zachowania niniejszej informacji licencyjnej oraz wskazania autora jako właściciela praw do tekstu. Treść licencji jest dostępna na stronie: http://creativecommons.org/licenses/by-nc-nd/3.0/pl/

Lingwistyka Stosowana 23: 3/2017, 135-149

\author{
Mariusz KRUK \\ Uniwersytet Zielonogórski \\ Joanna ZAWODNIAK \\ Uniwersytet Zielonogórski
}

\title{
Rozważania o zmiennym charakterze motywacji na lekcji języka angielskiego jako obcego wśród uczniów szkoły ponadgimnazjalnej
}

\begin{abstract}
:
A handful of reflections on motivational changes among EFL senior high school students

The present paper aims to examine the patterns of motivational variability in a group of 11 EFL senior high school students. It consists of two, theoretical and empirical, parts, the first of which will concentrate on motivation as seen through the lens of D. Larsen-Freeman's Complex Dynamic Systems Theory and on an overview of research into motivation conducted in light of the said theory. As regards the second part of the paper, it is meant to discuss the results obtained from a six-month-long quantitative study of changes in the subjects' levels of motivation during the EFL lessons. Data gathering tools included a general questionnaire referring to motivation, motivational grids and evaluation sheets.
\end{abstract}

\section{Wstęp}

Motywację definiuje się jako próbę, intencję i potrzebę osiągnięcia własnych celów, a także jako planowanie sposobu ich realizacji i decydowanie o wysiłku, jaki należy w ten proces włożyć (zob. H.D. Brown 1994, G.A. Melendy 2008, K.R. Scherer 1993). Motywacja jest zmienną ucznia, która, w stopniu większym niż zdolności językowe, programy nauczania i narzędzia glottodydaktyczne, wpływa na jego poczucie pewności siebie, pozytywny stosunek do przyswajanego języka i umiejętność komunikowania się w nim (zob. M.J. Guilloteax/ Z. Dörnyei 2008). W konsekwencji, za zmotywowanego ucznia można uznać osobę, która jest zdeterminowana do uczenia się języka bez względu na okoliczności i napotykane trudności (zob. G.A. Melendy 2008).

Na przestrzeni ostatniej dekady rozumienie konstruktu motywacji przeszło prawdziwą ewolucję, przestano go bowiem postrzegać jako zmienną o charakterze stabilnym (zob. R.C. Gardner 1985), a zaczęto zauważać tendencję motywacji do przechodzenia przez różne, wyższe bądź niższe poziomy natężenia: spostrzeżono nielinearność motywacji, dynamiczne i nieprzewidywalne współdziałanie w jej obrębie czynników czasowych i przestrzennych, jak też zaobserwowano brak jednoznacznego powiązania jej z procesami przyczynowo-skutkowymi (zob. W. Ahmed i in. 2011, Z. Dörnyei i in. 2006, S. Hotho 2000, D. Larsen-Freeman 2016). 
W świetle prowadzonych od ponad dekady badań nad motywacją, ukierunkowanych bardziej na procesy decydujące o jej przebiegu niż na jej produkt końcowy, zmienna ta jest percypowana jako jeden $\mathrm{z}$ wielu złożonych systemów dynamicznych, którego działanie jest uzależnione od pojawienia się i aktywności innych, wewnętrznie bądź zewnętrznie uwarunkowanych systemów współtworzących ekologię klasy językowej (zob. F. Waninge i in. 2014). Tychże systemów z ich zmiennością, złożonością, dynamicznością i współzależnością w procesie przyswajania języka dotyczy teoria złożonych systemów dynamicznych D. Larsen-Freeman (2016), w której kontekst wpisuje się niniejszy artykuł, zmierzający do przyjrzenia się fenomenowi motywacji z perspektywy zmian, jakim może ona podlegać $\mathrm{w}$ trakcie pojedynczych lekcji, jak też z lekcji na lekcję.

\section{Przegląd literatury}

\subsection{Motywacja w ujęciu tradycyjnym}

W najczęściej przywoływanej typologii mówi się o motywacji zewnętrznej i wewnętrznej, z których tę pierwszą definiuje się jako oczekiwanie wzmocnienia pozytywnego, rozumianego w kategoriach systemu nagradzania zewnętrznego (np. dobra ocena numeryczna lub obrazkowa, pochwała) będącego odpowiedzią nauczyciela na zachowania językowe ucznia (zob. H.D. Brown 1994). Natomiast motywacja wewnętrzna prowadzi do zachowań ukierunkowanych na otrzymanie nagród o charakterze mentalnym, jak samozadowolenie czy samorealizacja ucznia (zob. J.F. Chen i in. 2005, M. Wei 2007).

W drugiej popularnej typologii wskazuje się na motywację integracyjną, która wynika z potrzeby identyfikowania się z użytkownikami języka docelowego, jak też ich kulturą oraz motywację instrumentalną, która wypływa z bardziej praktycznych pobudek, jak zdanie egzaminu, dostanie się na uczelnię czy zdobycie intratnej posady. Jako jedni z pierwszych motywację integracyjną i instrumentalną omówili R.C. Gardner i W.E. Lambert (1959) w teorii postaw i motywacji.

J.F. Chen i in. (2005) osadzają motywację w kontekście kulturowym, przedstawiając ją jako zjawisko sterowane chińskim imperatywem, tj. określonymi oczekiwaniami i wymaganiami stawianymi przed członkami społeczności chińskiej i tajwańskiej, które odnoszą się do relacji pomiędzy dążeniem do uzyskania dobrych ocen a zjednaniem sobie szacunku grupy społecznej (zob. J.F. Chen i in. 2005).

Wreszcie K. Julkunen (2001) mówi o motywacji sytuacyjnej i zadaniowej, podkreślając tym samym znaczenie kontekstu i rodzaju wykonywanych czynności. W rezultacie czynności indywidualne i grupowe, a wśród nich i te oparte na współpracy i wzajemnym wsparciu, i te wynikające ze współzawodnictwa, mogą oddziaływać na motywację w różny sposób.

\subsection{Motywacja w ujęciu kognitywnym}

W podejście kognitywnym, w sposób szczególny uwzględniającym znaczenie wewnętrznych źródeł motywacji i nagród wewnętrznych, na uwagę zasługują dwie teo- 
rie, a mianowicie teoria wewnętrznych potrzeb D.P. Ausubela (1968) (the drive theory) i teoria hierarchii potrzeb A. Maslowa (1970) (hierarchy of needs theory).

Teoria D.P. Ausubela (1968) dotyczy związku pomiędzy wewnętrznymi potrzebami jednostki a jej działaniem i jakością tego działania. D.P. Ausubel wyróżnia 6 podstawowych potrzeb (tendencji/predyspozycji), jakie skłaniają ucznia do podjęcia aktywności. Są to potrzeby wiedzy, badania tego, co nieznane, sprawowania kontroli nad otoczeniem, aktywności fizycznej, stymulacji umysłowej, afektywnej i motorycznej oraz umocnienia własnego ,ja”. Nietrudno zauważyć, że każdy z tych czynników w mniejszym lub większym stopniu determinuje pracę ucznia w klasie językowej (zob. H.D. Brown 1994).

Teoria A. Maslowa (1970) jest próbą hierarchizacyjnej kategoryzacji potrzeb ludzkich od tych niższego rzędu (np. potrzeba jedzenia, snu, odpoczynku), przez te o charakterze społecznym (np. potrzeba przynależności do grupy, bezpieczeństwa, wolności), po te wyższego rzędu (np. poczucie spełnienia, poczucie własnego statusu jako jednostki). A. Maslow podkreśla, że spełnienie potrzeb wyższego rzędu uzależnione jest od zaspokojenia potrzeb niższego rzędu, co ma niewątpliwe odniesienie do procesu uczenia się języka

\subsection{Motywacja w ujęciu teorii złożonych systemów dynamicznych (complex dy- namic systems theory - CDST)}

Teoria złożonych systemów dynamicznych zakłada całościowe, czasowo i przestrzennie usytuowane współdziałanie różnorakich systemów uczestniczących i jednocześnie warunkujących proces przyswajania języka. Systemy te odnoszą się do ucznia (np. motywacja, style/strategie uczenia się, lęk językowy, nuda, poczucie własnej wartości), nauczyciela (np. kompetencje zawodowe i językowe, materiały nauczania, narzędzia glottodydaktyczne, teorie personalne) i środowiska uczenia się (np. atmosfera panująca podczas zajęć, relacje między poszczególnymi uczniami, a także pomiędzy uczniami a nauczycielem, fizyczne cechy klasy lekcyjnej), składając się tym samym na ekologię klasy językowej (zob. Z. Dörnyei 2009b, D. Larsen-Freeman 1997, 2016).

Można wyróżnić trzy podstawowe cechy złożonych systemów dynamicznych:

- zmianę, która wskazuje na ciągłe przeobrażenia, jakim podlega dany system w czasie i przestrzeni; np. poziomy motywacji mogą się zmieniać na przestrzeni określonego odcinka czasu i zarazem wchodzić w nieprzewidziane interakcje z innymi zmiennymi ucznia (zob. A. Henry 2015, S. Mercer 2011);

- stabilność dowodzącą istnienia sytuacji, w których badane systemy zachowują się $\mathrm{w}$ przewidywalny i niepodlegający zmianom sposób; przykładem potwierdzającym tę zasadę jest fosylizacja struktur językowych ucznia (zob. K. De Bot $i$ in. 2007);

- kontekst, który dotyczy oddziaływania czynników zewnętrznych (np. zachowania innych uczniów, kontrola nauczyciela, ograniczenia wynikające z fizycznych parametrów pomieszczenia lekcyjnego) na konkretny aspekt nauki języka przez jednostkę (zob. Z. Dörnyei 2009a, M. Verspoor i in. 2008). 
Warto wspomnieć o trzech modelach motywacji, które uwzględniają jej złożoność i dynamizm, a mianowicie o modelu M. Williams i R. Burdena (1997), modelu Z. Dörnyei’a i I. Ottó (1998) i modelu E. Ushiody (2009):

- w modelu M. Williams i R. Burdena (1997) motywacja przedstawiona jest jako proces składający się z 3 etapów: (1) przyczyna, dla której wykonuje się daną czynność, (2) podjęcie decyzji wykonania tej czynności, (3) wytrwanie w wykonywaniu tejże czynności.

- w modelu Z. Dörnyei’a i I. Ottó (1998) motywacja dzieli się na następujące 3 fazy: (1) fazę wstępną, w której dokonuje się wyboru celów i podejmuje się decyzję zainicjowania określonej czynności, (2) fazę właściwą, która dotyczy procesów wykonawczych i podtrzymywania towarzyszącej im motywacji, (3) fazę końcową, która ma charakter retrospektywny, jako że dotyczy ona ewaluacji wykonanej pracy, z której zostają wyciągnięte konstruktywne wnioski na przyszłość.

- w modelu E. Ushiody (2009) mówi się o wpływie czynników środowiskowych na uczniów języka docelowego, którzy odnajdują się w przeróżnych kulturowo i historycznie zdeterminowanych sytuacjach oddziałujących na ich motywację i tożsamość.

\subsection{Przegląd badań nad motywacją widzianą przez pryzmat CDST}

Badania nad motywacją jako zmienną ewoluującą, a zatem charakteryzującą się dynamizmem, nielinearnością i nieprzewidywalnością i w związku z tym przechodzącą przez różne stopnie natężenia badano z różnych, wyszczególnionych poniżej perspektyw:

- perspektywa pedagogiczna

- motywacja a materiały/programy nauczania i poziom biegłości językowej uczniów (zob. Y. Ajibade/ K. Ndubuda 2008, M. Liu 2007);

- perspektywa poznawcza

- motywacja a strategie uczenia się, ze szczególnym uwzględnieniem strategii metakognitywnych (zob. R. Feng/ H. Chen 2009, M.J. Guilloteaux/ Z. Dörnyei 2008);

- perspektywa afektywna

- motywacja a lęk językowy i zmiany w poczuciu własnej odrębności (zob. G. Yihong i in. 2007);

- motywacja a formowanie celów, podejmowanie wyborów i kontekst uczenia się (zob. G. A. Melendy 2008, W.C.V. Wu/ P.H.N. Wu 2008);

- perspektywa typologiczna

- przewaga motywacji instrumentalnej nad integracyjną u licealistów i studentów (zob. S. Rahman 2005);

- wpływ motywacji integracyjnej na redukowanie poziomu lęku językowego (zob. M. Wei 2007);

- perspektywa tzw. czynnika ludzkiego 
- nauczyciel jako najbardziej wpływowy czynnik ludzki w procesie motywowania ucznia języka obcego (znaczenie umiejętności tworzenia przyjaznej atmosfery, upraszczania formy przekazywanych informacji i wskazówek, kształtowania entuzjazmu uczniów, wzmocnienia pozytywnego, zawodowego zaangażowania i pasji (zob. R. Feng/ H. Chen 2009, M. Wei 2007);

- znaczenie grupy rówieśniczej ze szczególnym uwzględnieniem wzmocnienia pozytywnego i dostarczania wzorców zachowań zasługujących na modelowanie (zob. F.W.-M. Tam 2009);

- znaczenie rodziców z uwzględnieniem ich podejścia do przyswajanego przez ich dzieci języka obcego, biegłości, z jaką posługują się tym językiem, a także używania (bądź nie) tego języka w celach zawodowych (zob. G.N. Chambers 1999, R.C. Gardner 1985, E. Lindgren/ C. Muñoz 2013);

- perspektywa rozwojowa (ilościowo i jakościowo mierzone zmiany w poziomie motywacji w określonych odcinkach czasu; wzrost i spadek motywacji uczniów podczas pojedynczych lekcji, jak też z lekcji na lekcję).

Zauważono zależność zmian w poziomie motywacji od:

- $\quad$ warunków sprzyjających koncentracji, a także od równowagi pomiędzy rzeczywistymi umiejętnościami ucznia a stawianymi przed nim wyzwaniami (zob. J. Egbert 2003);

- pragmatycznego podążania ścieżką postawionych sobie celów, charakteru lekcji, rodzaju proponowanych czynności i czasu ich trwania (zob. M. Pawlak i in. 2014);

- $\quad$ stopnia atrakcyjności zajęć, relacji nauczyciela z uczniami, ich znużenia i godzinowego obciążenia zajęciami w skali tygodnia (zob. M. Kruk 2016).

\section{Projekt badawczy}

\subsection{Cel i pytania badawcze}

Celem projektu badawczego było bliższe przyjrzenie się zmianom w motywacji do uczenia się języka angielskiego podczas regularnie odbywających się lekcji tegoż języka w szkole ponadgimnazjalnej oraz określenie czynników mogących wpływać na rzeczone zmiany w motywacji. Autorzy badania poszukiwali odpowiedzi na następujące pytania badawcze:

1. Jak zmienia się poziom motywacji uczniów podczas pojedynczej jednostki lekcyjnej oraz z lekcji na lekcję?

2. Czy istnieją różnice $\mathrm{w}$ poziomie motywacji pomiędzy uczniami z wysokim, średnim i niskim poziomem motywacji podczas pojedynczej jednostki lekcyjnej oraz z lekcji na lekcję?

3. Jakie czynniki mogą wpływać na zmiany w poziomie motywacji u badanych uczniów?

\subsection{Uczestnicy}

W badaniu uczestniczyła 11-osobowa grupa uczniów polskiej szkoły ponadgimnazjalnej. Spośród wspomnianej grupy uczniów dodatkowo wybrane zostały trzy osoby charakteryzujące się, odpowiednio, wysokim, średnim i niskim poziomem motywacji do 
uczenia się języka angielskiego (tabela 1). Poziom motywacji został zmierzony na podstawie ankiety dotyczącej motywacji (zob. sekcja 2.3).

\begin{tabular}{|l|c|c|}
\hline & Poziom motywacji & Odchylenie standard. \\
\hline Uczeń A & 4,55 & 1,04 \\
\hline Uczeń B & 3,90 & 1,14 \\
\hline Uczeń C & 2,62 & 1,15 \\
\hline Grupa $(\mathrm{n}=11)$ & 3,68 & 0,67 \\
\hline
\end{tabular}

Tabela 1. Poziom motywacji uczestników badania.

Uczestnikami badania byli uczniowie czwartej klasy szkoły ponadgimnazjalnej w wieku 19 lat. Badani uczniowie uczyli się języka angielskiego średnio od 6,64 lat, a ich ogólny poziom językowy można ocenić jako słaby. Podobnie rzecz się ma w przypadku samooceny badanych uczniów. Uczestnicy badania motywowani byli głównie chęcią zaliczenia przedmiotu i ukończenia szkoły (tabela 2). Należy także dodać, że badani uczniowie mieli dwie lekcje języka angielskiego w tygodniu.

\begin{tabular}{|c|c|c|c|c|c|c|c|}
\hline \multirow[b]{2}{*}{ 㺼 } & \multirow{2}{*}{ 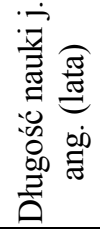 } & \multirow{2}{*}{ 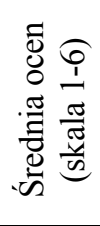 } & \multirow{2}{*}{ 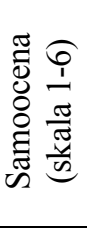 } & \multicolumn{4}{|c|}{ Sprawności językowe / podsystemy } \\
\hline & & & & $\begin{array}{l}\text { Najbardziej } \\
\text { ulubione }\end{array}$ & $\begin{array}{l}\text { Najmniej } \\
\text { ulubione }\end{array}$ & $\begin{array}{l}\text { Łatwe do } \\
\text { nauki }\end{array}$ & $\begin{array}{l}\text { Trudne } \\
\text { do nauki }\end{array}$ \\
\hline A & 6 & 4 & 3,5 & pisanie & słownictwo & pisanie & gram. \\
\hline $\mathrm{B}$ & 7 & 3 & 3 & słownictwo & pisanie & słownictwo & gram. \\
\hline $\mathrm{C}$ & 6 & 2 & 2 & słownictwo & gramatyka & słownictwo & gram. \\
\hline $\begin{array}{c}\text { Grupa } \\
\text { Śred. } \\
\text { odch. st. }\end{array}$ & $\begin{array}{l}6,64 \\
2,29\end{array}$ & $\begin{array}{l}2,64 \\
0,50\end{array}$ & $\begin{array}{l}2,64 \\
0,50\end{array}$ & $\begin{array}{l}\text { czytanie } \\
\text { słownictwo }\end{array}$ & $\begin{array}{l}\text { gramatyka } \\
\text { słownictwo }\end{array}$ & $\begin{array}{l}\text { słownictwo } \\
\text { wymowa }\end{array}$ & gram. \\
\hline
\end{tabular}

Tabela 2. Uczestnicy badania.

\subsection{Procedura, pobór i analiza danych}

Badanie zostało przeprowadzone w trakcie semestru zimowego i objęło 25 lekcji języka angielskiego (45 minut każda). Uczestnicy badania nauczani byli przez jednego $\mathrm{z}$ autorów artykułu, który był także nauczycielem języka angielskiego badanej grupy uczniów. Podczas lekcji wykorzystano obowiązujący podręcznik, tj. Repetytorium maturalne autorstwa M. Umińskiej, B. Hastingsa, D. Chandler i H. Mrozowskiej. Wszystkie lekcje zaplanowane i poprowadzone zostały w podobny sposób. Ogólnie rzecz ujmując, typowa lekcja języka angielskiego rozpoczynała się od czynności administracyjnych (np. sprawdzanie obecności) oraz sprawdzenia zadania domowego i/lub krótkiej powtórki materiału z ostatniej lekcji. Następnie nauczyciel prezentował i omawiał temat i cele lekcji. Po tym uczniowie proszeni byli o wykonanie stosownych ćwiczeń, podczas których poznawali nowy materiał, doskonaląc sprawności językowe. Pod koniec lekcji nauczyciel podsumowywał omawiamy materiał i zadawał pracę domową.

W badaniu wykorzystano następujące instrumenty zbierania danych: 
- kwestionariusz osobowy - kwestionariusz dostarczył danych związanych z opisem uczestników badania; został on wypełniony przez uczestników przed rozpoczęciem badania;

- ankieta dotyczaca motywacji - ankieta zawierała 42 stwierdzenia w sześciostopniowej skali Likerta (1 - zdecydowanie nie zgadzam się, 6-zdecydowanie zgadzam się); ankieta, której głównym celem było określenie ogólnego poziomu motywacji do uczenia się języka angielskiego, została sporządzona na podstawie innych dostępnych w literaturze przedmiotu ankiet zaprojektowanych przez S. Ryana (2005), T. Taguchi i in. (2009) oraz K. Csizér i J. Kormos (2009); stwierdzenia znajdujące się w ankiecie dotyczyły, między innymi, takich elementów jak zachowania motywacyjne, idealna osobowość drugiego języka, ,ja idealnego języka drugiego", ,ja powinnościowego języka drugiego”, doświadczenia uczenia się języka drugiego, własna efektywność w języku obcym czy zainteresowanie językiem angielskim; wartość współczynnika alpha Cronbacha była zadowalająca (Z. Dörnyei 2007: 207) i wyniosła 0,71; ankieta została wypełniona przez uczniów w trakcie trwania badania;

- arkusz śródlekcyjny - arkusz został zaprojektowany tak, aby dostarczyć informacji związanych z poziomem motywacji uczniów podczas każdej lekcji; uczniowie poproszeni zostali o dokonanie samooceny poziomu motywacji podczas lekcji siedem razy (tj. co pięć minut, począwszy od 10 minuty lekcji) w skali od 1 (minimalny poziom) do 7 (maksymalny poziom); arkusz śródlekcyjny to zmodyfikowana wersja instrumentu wykorzystanego przez M. Pawlaka (2012);

- arkusz ewaluacyjny - arkusz został utworzony na podstawie instrumentu wykorzystanego przez M. Pawlaka (2012); jego celem było dostarczenie informacji dotyczących oceny lekcji przez uczestników badania; arkusz ewaluacyjny to w zasadzie (siedmiostopniowa) skala semantyczna, której bieguny oznaczone były dwoma antonimami (np. interesujący - nudny; niekonkretny - konkretny; niezadowalający - zadowalający; absorbujący - monotonny); uczniowie poproszeni zostali o wypełnienie arkusza pod koniec każdej lekcji;

- plany lekcji - ich celem było umożliwienie powiązania zmian w poziomie motywacji uczniów z częścią każdej lekcji, zadaniami i czynnościami.

Zebrane dane poddano analizie ilościowej. Obliczono średnie i odchylenie standardowe. Należy także dodać, że wszystkie ankiety i arkusze wypełnione zostały przez uczestników badania anonimowo i wszyscy uczestnicy wyrazili zgodę na wzięcie udziału w badaniu.

\section{Rezultaty}

\subsection{Grupa}

Analiza danych zebranych na podstawie arkuszy śródlekcyjnych z 25 lekcji języka angielskiego ujawniła wystąpienie pewnych zmian w poziomie motywacji badanej grupy uczniów. Dokładniej rzecz ujmując, średni poziom motywacji wskazany przez wszystkich uczestników badania był najwyższy w początkowej części przeprowadzonych lekcji (tj. podczas pierwszych 15 minut), po czym następował powolny i systematyczny jej spadek, trwający do końcowych minut zajęć (rysunek 1 i tabela 3). 


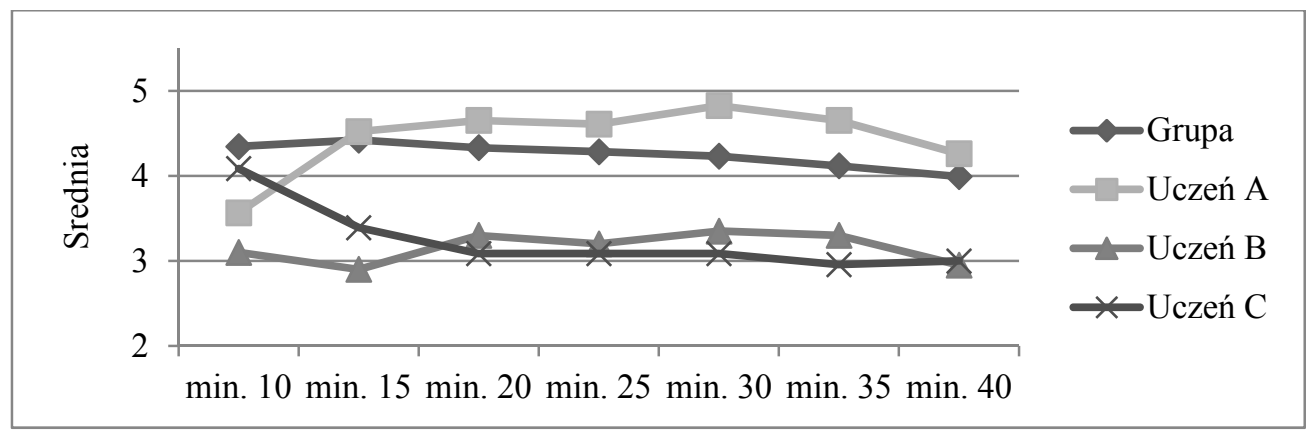

Rysunek 1. Zmiany w poziomie motywacji dla całej grupy i indywidualnych uczniów podczas lekcji.

\begin{tabular}{|l|c|c|c|c|c|c|c|c|}
\hline & min. 10 & min. 15 & \multicolumn{7}{c|}{$\min .20$} & $\min .25$ & $\min .30$ & $\min .35$ & $\min .40$ \\
\cline { 2 - 8 } & \multicolumn{7}{|c|}{ Srednia (odchylenie standardowe) } \\
\hline Grupa & 4,34 & 4,42 & 4,33 & 4,28 & 4,23 & 4,12 & 3,99 \\
$(\mathrm{n}=11)$ & $(0,65)$ & $(0,69)$ & $(0,54)$ & $(0,55)$ & $(0,55)$ & $(0,45)$ & $(0,44)$ \\
\hline Uczeń & 3,57 & 4,52 & 4,65 & 4,61 & 4,83 & 4,65 & 4,26 \\
A & $(1,38)$ & $(0,73)$ & $(0,71)$ & $(0,94)$ & $(0,83)$ & $(0,78)$ & $(1,01)$ \\
\hline Uczeń & 3,10 & 2,90 & 3,30 & 3,20 & 3,35 & 3,30 & 2,95 \\
B & $(0,55)$ & $(0,64)$ & $(0,57)$ & $(0,83)$ & $(0,81)$ & $(0,92)$ & $(0,94)$ \\
\hline Uczeń & 4,09 & 3,39 & 3,09 & 3,09 & 3,09 & 2,96 & 3,00 \\
C & $(1,65)$ & $(1,59)$ & $(1,38)$ & $(1,38)$ & $(1,31)$ & $(0,98)$ & $(0,95)$ \\
\hline
\end{tabular}

Tabela 3. Średnia i odchylenie standardowe dla zmian w poziomie motywacji dla catej grupy i indywidualnych uczniów podczas lekcji.

Analiza danych zebranych na podstawie ankiet ewaluacyjnych pokazała natomiast pewne zmiany w poziomie motywacji uczniów, jakie zachodziły z jednej lekcji na kolejną. Za najbardziej motywujące zajęcia uczniowie uznali lekcje 3 i 11 (pisanie; średnie odpowiednio: 5,06 i 5,04) oraz 24 (mówienie i gramatyka; średnia: 5,00), a za najmniej motywujące - lekcje 5 i 20 (test; średnie odpowiednio: 4,07 i 4,16). Ponadto największa różnica w ocenie najbardziej i najmniej motywującej lekcji (tj. pomiędzy lekcjami 3 i 5) dla całej grupy wyniosła 0,99 . Należy także dodać, że badani uczniowie najczęściej ocenili przeprowadzone lekcje jako interesujące, godne uwagi i przyjemne (średnie i wartości odchylenia standardowego wyniosły odpowiednio: 4,97, 0,35;4,80, $0,20 \mathrm{i}$ $4,76,0,41)$.

\subsection{Uczniowie indywidualni}

\section{Uczeń A (wysoce zmotywowany)}

Analiza danych zebranych na podstawie arkuszy śródlekcyjnych ze wszystkich lekcji ujawniła, że uczeń A zdeklarował najniższy poziom motywacji na samym początku (minuta 10) oraz na końcu lekcji (minuta 40), a najwyższy na początku drugiej połowy zajęć (tj. 30 minuta). Ponadto poziom motywacji ucznia A charakteryzował się mniejszymi wahaniami, występującymi od minuty 15 do 35 (rysunek 1). Należy jednak zaznaczyć, że najniższe poziomy motywacji ucznia A odnotowane na początku i końcu 
lekcji cechują dość wysokie wartości odchylenia standardowego, co świadczy o zróżnicowanym poziomie motywacji w rzeczonych momentach lekcji (tabela 3 ).

Analiza danych pochodzących $\mathrm{z}$ arkuszy ewaluacyjnych ujawniła także zmiany $\mathrm{w}$ poziomie motywacji z lekcji na lekcję badanego ucznia. I tak, uczeń A ocenił lekcje 11, 16 i 3 (pisanie; średnie odpowiednio: 7,00; 6,14 i 5,71), 13 (słuchanie i czytanie; średnia 5,57), 19 (mówienie i gramatyka; średnia: 5,57) i 22 (słownictwo; średnia: 5,57) jako najbardziej motywujące, natomiast najmniej motywujące dla tego ucznia okazały się lekcje 5 i 20 (test; średnie odpowiednio: 3,29 i 4,14) i 17 (słownictwo; średnia: 4,57). Największa różnica w ocenie najbardziej i najmniej motywującej lekcji (tj. lekcji 11 i 5) wyniosła 3,71. Należy także dodać, że dla ucznia A lekcje były z jednej strony godne uwagi i konkretne (średnie i odchylenie standardowe odpowiednio: 6,39; 0,78 i 5,48; $0,85)$, a z drugiej strony umiarkowanie atrakcyjne $(4,83 ; 1,03)$ i umiarkowanie absorbujące $(4,87 ; 0,97)$.

\section{Uczeń B (średnio zmotywowany)}

Poziom motywacji ucznia B charakteryzuje się większą stabilnością od poziomu motywacji zdeklarowanego przez ucznia A, niemniej i tutaj zauważyć można pewne wahania w jej poziomie. I tak, uczeń B był najmniej zmotywowany w początkowej części lekcji (w szczególności w piętnastej minucie jej trwania) oraz na samym końcu zajęć (minuta 40) (rysunek 1). Należy także zauważyć, że wartości odchylenia standardowego cechuje tendencja wzrostowa, co świadczy o pewnym zróżnicowaniu w poziomie motywacji podczas zajęć (tj. od minuty 10 do 40 ) na przestrzeni wszystkich lekcji (tabela 3 ).

Pewne wahania w poziomie motywacji z lekcji na lekcję zauważyć można także w przypadku ucznia B, choć, w przeciwieństwie do ucznia A, cechuje je większa stabilność. Tutaj bowiem największa różnica w ocenie najbardziej i najmniej motywującej lekcji (tj. pomiędzy lekcjami 12 i 14 a 11) wyniosła 1,86. Tak czy inaczej, uczeń B ocenił lekcje 12 (słownictwo; średnia: 5,43), 14 (mówienie i gramatyka; średnia: 5,43), 15 (słuchanie i czytanie; średnia: 5,00) i 17 (słownictwo; średnia: 5,00) jako najbardziej motywujące zajęcia, a lekcje 11 (pisanie; średnia: 3,57), 22 (słownictwo; średnia: 3,57) i 24 (mówienie i gramatyka; średnia: 3,86) jako najmniej motywujące. W ogólnej ocenie lekcji dokonanej przez ucznia B przeważały oceny: interesujące (średnie i odchylenie standardowe odpowiednio: 5,$25 ; 0,55)$, przyjemne $(4,60 ; 0,75)$ oraz konkretne $(4,50$; $0,76)$.

\section{Uczeń C (nisko zmotywowany)}

Poziom motywacji ucznia $\mathrm{C}$ różni się zasadniczo od poziomów wskazanych przez uczniów A i B. Wynika to $\mathrm{z}$ faktu, że uczeń $\mathrm{C}$ czuł się najbardziej zainteresowany i zaangażowany w to, co działo się podczas zajęć w pierwszych minutach ich trwania (tj. do 15 minuty włącznie). Po tym czasie jednak poziom motywacji rzeczonego ucznia stabilizował się i pozostawał na prawie niezmiennym poziomie do końca lekcji (rysunek 1). Należy jednak zauważyć, że średnie poziomu motywacji ucznia $C$ podczas lekcji w różnych odstępach czasowych były bardzo zróżnicowane, co widoczne jest w wysokich wartościach odchylenia standardowego (tabela 3). Ponadto wartości te cechuje tenden- 
cja malejąca (najniższe odnotowano w przypadku minuty 35 i 40), co świadczy o znacznym zróżnicowaniu poziomu zainteresowania i zaangażowania ucznia $\mathrm{C} \mathrm{w}$ poszczególne zajęcia i czynności lekcyjne od początku ich trwania.

Analiza danych zebranych na podstawie arkuszy ewaluacyjnych pokazała także spore zmiany w poziomie motywacji ucznia $\mathrm{C}$ z lekcji na lekcję. Najwyżej ocenił on lekcje 24 (mówienie i gramatyka; średnia: 5,14), 6 (słownictwo: średnia: 5,14) oraz 11 (pisanie; średnia: 5,00), a najniżej lekcje 7 (słuchanie i czytanie; średnia: 3,00), 8 (mówienie i gramatyka; średnia: 3,14), 18 (słuchanie i czytanie; średnia: 3,14), 19 (mówienie i gramatyka; średnia: 3,14) i 21 (słownictwo i gramatyka; średnia: 3,14). Największa różnica w ocenie najbardziej i najmniej motywującej lekcji (tj. lekcji 24 i 6 oraz 7) wyniosła 2,14. Ponadto dla ucznia $\mathrm{C}$ lekcje były raczej interesujące (wartość średnich i odchylenie standardowe odpowiednio: 4,$61 ; 1,27)$ i przyjemne $(4,52 ; 1,04)$, jednak, inaczej niż uczniowie A i B, uczeń C ocenił je również jako dość monotonne $(2,87 ; 1,10)$.

\section{Dyskusja i zakończenie}

\subsection{Pytanie badawcze nr 1}

Uzyskane wyniki wskazują na najwyższy poziom motywacji w całej grupie badanych uczniów na początku lekcji i na systematyczny jej spadek w dalszych fazach zajęć. Można to thumaczyć dużymi oczekiwaniami uczniów i wstępnym entuzjazmem, który zaczął się wyczerpywać w obliczu pojawiających się na dalszych etapach lekcji zadań wymagających pewnej dozy wysiłku poznawczo-językowego (np. pisanie listu, rozwiązywanie krzyżówki, uzupełnianie definicji, odgrywanie scenek). Mogło wiązać się to ze stosunkowo niskim poziomem kompetencji językowych uczniów, jak też ich niską samooceną w tym zakresie. Zjawisko to można również wyjaśnić zaznaczając, że początek każdego, nie tylko językowego, przedsięwzięcia zawsze wydaje się obiecujący, jednak w miarę realizowania go, zapas energii i zaangażowania okazuje się niewystarczający. O spadku początkowego entuzjazmu użytkowników języka jest mowa w modelu akulturacji J. Schumanna (1990); na użytek niniejszego badania można przywołać tu kwestię psychologicznego dystansu, który w przypadku tej grupy uczniów mógł być zbyt duży, a zatem postrzegali oni siebie jako osoby nie w pełni zdolne do wykonania konkretnych zadań. Etapy akulturacji pokazują, że euforia, entuzjazm i żywe zainteresowanie są stanami przelotnymi, a zatem krótkotrwałymi, po których następuje faza rozczarowania, frustracji i zniechęcenia. Są to jednak również okresy przejściowe, po których u uczniów zaczyna kształtować się stabilność socjokognitywna, co w pewnym stopniu można było zauważyć w badanej grupie uczniów.

Można też zaobserwować różnice w poziomach motywacji zmieniających się z lekcji na lekcję. Warto zauważyć, że uczniowie czuli się najbardziej zmotywowani podczas pisania wiadomości (lekcja 3) i listu z zażaleniem (lekcja 11), co może wiązać się z instrumentalną orientacją tychże uczniów i dążeniem do nabycia umiejętności posługiwania się językiem w praktyce zawodowej. Najniższy poziom motywacji przypadł na dwa zajęcia w całości poświęcone testowi, co można wyjaśnić lękiem przed weryfikacją zdobytych umiejętności i/lub obawą przed negatywną ewaluacją wykonanej pracy (zob. 
P.D. McIntyre 1995, L. Woodrow 2006). Ogólna ocena wszystkich zajęć jako przyjemnych i interesujących wskazuje, że mimo wystąpienia dość znaczącego dystansu psychologicznego, tj. stopnia, w jakim uczniowie postrzegali własne możliwości w stosunku do wykonywanych zadań, potrafili oni docenić właściwą wartość tychże zadań. Może to oznaczać, że niewystarczającym kompetencjom językowym towarzyszyła charakterystyczna dla wieku ponadgimnazjalnego dojrzałość poznawcza.

\subsection{Pytanie badawcze $\mathrm{nr} 2$}

Na podstawie zebranych danych badawczych można wnioskować, że między uczniami o wysokim, średnim i niskim poziomie motywacji występują pewne różnice. Zaobserwowane u uczniów A, B, i C poziomy motywacji odbiegają od tendencji charakteryzujących całą grupę 11 uczniów, u których najwyższy poziom motywacji odnotowano na samym początku lekcji, po czym następował sukcesywny jej spadek aż do końca zajęć. I tak, początkowa i końcowa faza lekcji okazały się okresem najniższego poziomu motywacji u ucznia A, zaś najwyższy jej poziom przypadł na początek drugiej połowy lekcji. Podobnie do ucznia A, u ucznia B dostrzeżono najniższy poziom motywacji na początku i na końcu lekcji. Jednocześnie trudno doszukać się momentów, w których poziom motywacji ucznia B byłby zdecydowanie wysoki, można jednak ogólnie skonstatować, że był on bardziej zmotywowany w dalszych częściach lekcji. Natomiast do innych wniosków niż w przypadku uczniów A i B można dojść w odniesieniu do ucznia $\mathrm{C}$, który był najbardziej zaangażowany w czasie początkowych minut lekcji, następnie zaś poziom jego motywacji obniżał się i osiągał stabilność, która trwała aż do końcowych minut lekcji. Dane te skłaniają do wniosku, że najmniej zmotywowany uczeń przystępował do lekcji z dość dużymi oczekiwaniami i zasobem energii, który z upływem czasu redukował się. Można przypuszczać, że uczniowie wysoce i średnio zmotywowani (A i B) wykazali bardziej realistyczne podejście do zajęć lekcyjnych jako czasu przeznaczonego na przyswojenie pewnych treści, które warto poznać niezależnie od stopnia, w jakim pokrywałyby się one z wcześniejszymi oczekiwaniami. Czynnikiem, jaki odgrywał pewną rolę u dwóch bardziej zmotywowanych uczniów mogła być użyteczność wykonywanych zadań, co pokrywa się z ich oceną. Uczniowie A i B podkreślali konkretność czynności lekcyjnych wspominając jednocześnie o ich umiarkowanej atrakcyjności (uczeń A), zaś najsłabiej zmotywowany uczeń $C$ podkreślił monotonny charakter lekcji, co sugeruje, że użyteczność poznawanego materiału i możliwość wykorzystania go w przyszłości jest dla niego mniej ważna niż stopień, w jakim uważa on ten materiał za efektowny.

Odnosząc się do poziomów motywacji zmieniających się z lekcji na lekcję, i tu również można zauważyć pewne prawidłowości. Otóż u ucznia A dostrzega się związek pomiędzy wyższym poziomem motywacji a preferencjami czynności pisemnych, gdyż z sześciu lekcji, na które przypada najwyższy poziom motywacji trzy były w jakimś stopniu poświęcone rozwijaniu sprawności pisania. Natomiast u uczniów B i C taka korelacja nie występuje, jako że lekcje, w czasie których byli oni najbardziej zmotywowani dotyczyły różnorodnych zagadnień językowych bez szczególnego wskazania na jedno z nich. W przypadku uczniów B i C poziom motywacji można zatem bardziej 
odnosić do typu zadań (otwartych bądź zamkniętych) niż do samych sprawności językowych czy podsystemów języka. Uczeń B wykazał najwyższy poziom motywacji podczas wykonywania zadań zamkniętych (porównywanie, uzupełnianie, wybieranie z wielu opcji), natomiast był najmniej zmotywowany pracując nad zadaniami otwartymi (pisanie listu) i gramatycznymi (uzupełnianie luk właściwymi formami przeszłymi czasowników). Co do ucznia C, sytuacja jest odwrotna, gdyż najbardziej motywujące były dla niego zadania otwarte (np. pisanie listu) i pewne zagadnienia gramatyczne (uzupelnianie luk właściwymi formami przeszłymi czasowników), zaś najniższy poziom motywacji dotyczył lekcji z zadaniami zamkniętymi (wielokrotny wybór, prawda/fałsz, uzupełnianie). Wyższa motywacja ucznia $\mathrm{C}$ podczas wykonywania zadań otwartych potwierdza wspomnianą już hipotezę o stosunkowo wysokich oczekiwaniach, jakie miał on na samym początku lekcji. Najwidoczniej były to zadania w jego mniemaniu atrakcyjne, w przeciwieństwie do zadań zamkniętych, które według wszelkiego prawdopodobieństwa uznał on za monotonne. Zastanawiać może fakt, że jedynie uczeń A ocenił test jako zajęcie najmniej motywujące, co można tłumaczyć na dwa odrębne sposoby: z jednej strony uczeń ów mógł oczekiwać innych, bardziej złożonych zadań, które motywowałyby go do większego zaangażowania i wysiłku, z drugiej zaś strony mógł też postrzegać swoje zdolności do wykonania poleceń testowych w kategoriach dużego dystansu psychologicznego, czyli jako znikome, co mogło zniechęcić go do pracy nad testem. Na etapie przeprowadzonego przez autorów tego artykułu badania ilościowego nie da się jednak jednoznacznie tej kwestii rozstrzygnąć.

\subsection{Pytanie badawcze nr 3}

Zaobserwowane i opisane zmiany w poziomie motywacji u trzech badanych uczniów można powiązać z innymi zmiennymi zarówno o charakterze poznawczym, jak i afektywnym. Z obserwacji nauczyciela-badacza prowadzącego lekcje, jak też z kwestionariusza osobowego wynika, że poziom kompetencji językowych uczniów był niski, można więc domniemywać, iż oddziaływał on na ich motywację. Trudno jednak stwierdzić, u którego ucznia kompetencje te były najniższe i czy występujące w tym zakresie różnice między tymi trzema uczniami były istotne. Do zgłębienia tej kwestii na pewno przyczynilyby się dalsze badania, tym razem jednak o charakterze jakościowym (np. wywiad pogłębiony i studium przypadku).

Niewątpliwe zainteresowanie może też wzbudzać niski poziom motywacji podczas zadań testowych u ucznia A, u którego ogólny poziom motywacji był notabene najwyższy. Przypuszczalnie, wystąpiła tu zależność niższego poziomu motywacji od innej zmiennej, np. od lęku językowego lub niskiego poczucia własnej wartości, co mogło prowadzić ucznia A do braku wiary w możliwość pomyślnego ukończenia testu. Ponadto mogła również wystąpić zależność pomiędzy motywacją a stylami i/lub strategiami uczenia się, aby to jednak stwierdzić niezbędne są dalsze badania ukierunkowane na zdiagnozowanie dominujących stylów i preferencji co do stosowania określonych strategii.

Konkludując, należy zaznaczyć, że specyfika ekologii klasy językowej niewątpliwie wymaga triangulacji danych, która wzbogaciłaby interpretację uzyskanych wyników o 
perspektywę jakościową. Zważywszy, że w centrum uwagi autorów niniejszego artykułu znajdowało się jedynie trzech uczniów, studium przypadku ze swoim idiograficznym i heurystycznym charakterem mogłoby stać się satysfakcjonującym dopełnieniem opisanych danych numerycznych. Niemniej, przedstawione powyżej wyniki zdają się potwierdzać założenia zawarte w teorii złożonych systemów dynamicznych D. Larsen-Freeman (2016). Trudno bowiem nie uznać motywacji za jeden $\mathrm{z}$ takich systemów, który wchodzi w różnorodne, niejednokrotnie trudne do przewidzenia i asymetrycznie zorganizowane interakcje $\mathrm{z}$ innymi systemami, jakie $\mathrm{w}$ innym czasie $\mathrm{i} \mathrm{w}$ innych warunkach mogłyby przynieść rezultaty odmienne od uzyskanych w wyniku opisanego tu badania.

\section{Bibliografia}

Ahmed, W./ G. Van der Werf/ A. Minnaert/ H. Kuyper (2011), Students' daily emotions in the classroom: Intra-individual variability and appraisal correlates, (w:) „British Journal of Educational Psychology” 80, 583-597.

Ajibade, Y./ K. Ndububa (2008), Effects of word games, culturally relevant songs, and stories on students' motivation in a Nigerian English language class, (w): „TESL Canada Journal/ Revue TESL de Canada” 25 (2), 27-48.

Ausubel, D.P. (1968), Educational Psychology: A Cognitive View. New York: Holt, Rinehart and Winston.

Brown, H.D. (1994), Teaching by Principles: An Interactive Approach to Language Pedagogy. Upper Saddle River, NJ.

Chambers, G.N. (1999), Motivating Language Learners. Clevedon, UK.

Chen, J.F./ C.A. Warden/ H.T. Chang (2005), Motivators that do not motivate: The case of Chinese EFL learners and the influence of culture on motivation, (w:) „TESOL Quarterly” 39 (4), 609-633.

Csizér, K./ J. Kormos (2009), Learning experiences, selves and motivated learning behavior: A comparative analysis of structural models for Hungarian secondary and university learners of English, (w:) Z. Dörnyei/ E. Ushioda (red.), Motivation, Language, Identity and the L2 Self. Bristol, 98-119.

De Bot, K./ W. Lowie/ M. Verspoor (2007), A dynamic systems theory approach to second language acquisition, (w:) „Bilingualism: Language and Cognition” 10, $7-21$.

Dörnyei, Z. (2007), Research Methods in Applied Linguistics. Oxford.

Dörnyei, Z. (2009a), Individual differences: Interplay of learner characteristics and learning environment, (w:) „Language Learning” 59, 230-248.

Dörnyei, Z. (2009b), The Psychology of Second Language Acquisition. Oxford.

Dörnyei, Z./ I. Ottó (1998), Motivation in action: A process model of L2 motivation, (w:) „Working Papers in Applied Linguistics (Thames Valley University, London)" 4, 43-69.

Dörnyei, Z./ K. Csizér/ N. Németh (2006), Motivation, Language Attitudes and Globalisation: A Hungarian Perspective. Clevedon, UK. 
Egbert, J. (2003), A study of flow theory in the foreign language classroom, (w:) „The Modern Language Journal" 87, 499-518.

Feng, R./ H. Chen (2009), An analysis on the importance of motivation and strategy in postgraduates English acquisition, (w:) ,English Language Teaching” 2 (3), 93-97.

Gardner, R. C. (1985), Social Psychology and Second Language Learning: The Role of Attitudes and Motivation. London.

Gardner, R.C./ W.E. Lambert (1959), Motivational variables in second-language acquisition, (w:) „Canadian Journal of Psychology” 13 (4), 266-272.

Guilloteax, M.J./ Z. Dörnyei (2008), Motivating language learners: A classroom-oriented investigation of the effects of motivational strategies on student motivation, (w:) ,TESOL Quarterly” 42 (1), 55-77.

Henry, A. (2015), The dynamics of L3 motivation: A longitudinal interview/observation-based study, (w:) Z. Dörnyei/ P.D. MacIntyre/ A. Henry (red.), Motivational Dynamics in Language Learning. Bristol, 315-342.

Hotho, S. (2000), "Same" or "different"? A comparative examination of classroom factors in second language settings, (w:) „Foreign Language Annals” 33, 320329.

Julkunen, K. (2001), Situation and task specific motivation in foreign language learning, (w:) Z. Dörnyei/ R. Schmidt (red.), Motivation and Second Language Acquisition. Honolulu, HI, 29-43.

Kruk, M. (2016), Temporal fluctuations in foreign language motivation: Results from a longitudinal study, (w:) „Iranian Journal of Language Teaching Research” 4 (2), 1-17.

Larsen-Freeman, D. (1997), Chaos/complexity science and second language acquisition, (w:) ,Applied Linguistics” 18, 140-164.

Larsen-Freeman, D. (2016), Classroom-oriented research from a complex systems perspective, (w:) „Studies in Second Language Learning and Teaching” 6 (3), 377-393.

Lindgren, E./ C. Muñoz (2013), The influence of exposure, parents, and linguistic distance on young European learners' foreign language comprehension, (w:) „International Journal of Multilingualism” 10, 105-129.

Liu, M. (2007), Chinese students' motivation to learn English at the tertiary level, (w:) „Asian EFL Journal” 9 (1), 126-146.

Maslow, A. (1970), Motivation and Personality. New York.

MacIntyre, P.D. (1995), How does anxiety affect second language learning? A reply to Sparks and Ganschow, (w:) „The Modern Language Journal” 79, 90-99.

Melendy, G.A. (2008), Motivating writers: The power of choice, (w:) „Asian EFL Journal" 10 (3), 187-198.

Mercer, S. (2011), Language learner self-concept: Complexity, continuity and change, (w:) ,System” 39, 335-346.

Pawlak, M. (2012), The dynamic nature of motivation in language learning, (w:) „Studies in Second Language Learning and Teaching” 2, 249-278.

Pawlak, M./ A. Mystkowska-Wiertelak/ J. Bielak (2014), Another look at temporal 
variation in language learning motivation: Results of a study, (w:) M. Pawlak/ L. Aronin (red.), Essential Topics in Applied Linguistics and Bilingualism: Studies in Honor of David Singleton. Heidelberg-New York, 89-109.

Rahman, S. (2005), Orientations and motivation in English language learning: A study of Bangladeshi students at undergraduate level, (w:) „Asian EFL Journal” 7 (1), 1-25.

Ryan, S. (2005), Motivational Factors Questionnaire. Nottingham.

Scherer, K.R. (1993), Plato's legacy: Relationships between cognition, emotion, and motivation. Paper presented at the Société Psychologique de Québec. Québec, Canada.

Schumann, J. (1990), Extending the scope of the acculturation/pidginization model to include cognition, (w:) ,TESOL Quarterly” 24, 667-684.

Taguchi, T./ M. Magid/ M. Papi (2009), The L2 motivational self system among Japanese, Chinese and Iranian learners of English: A comparative study, (w:) Z. Dörnyei/ E. Ushioda (red.), Motivation, Language Identity and the L2 Self. Bristol, 66-97.

Tam, F.W.-M. (2009), Motivation in learning a second language: Exploring the contributions of family and classroom processes, (w:) „The Alberta Journal of Educational Research" 55, 73-91.

Ushioda, E. (2009), A person-in-context relational view of emergent motivation, self and identity, (w:) Z. Dörnyei/ E. Ushioda (red.), Motivation, Language Identity and the L2 Self. Bristol, 215-228.

Verspoor, M./ W. Lowie/ M. Van Dijk (2008), Variability in second language development from a dynamic systems perspective, (w:) ,The Modern Language Journal" 92, 214-231.

Waninge, F./ Z. Dörnyei/ K. de Bot (2014), Motivational dynamics in language learning: Change, stability, and context, (w:) „The Modern Language Journal” 98 (3), $704-723$.

Wei, M. (2007), The interrelatedness of affective factors in EFL learning: An examination of motivational patterns in relation to anxiety in China, (w:),,TESL-EJ" $11(1), 1-23$.

Williams, M./ R. Burden (1997), Psychology for Language Teachers: A Social Constructivist Approach. Cambridge.

Woodrow, L. (2006), Anxiety and speaking English as a second language, (w:) „Regional Language Centre Journal" 37 (3), 308-328.

Wu, W.C.V./ P.H.N. Wu (2008), Creating an authentic EFL learning environment to enhance student motivation to study English, (w:) „Asian EFL Journal” 10 (4), 211-226.

Yihong, G./ Z. Yuan/ C. Ying/ Z. Yan (2007), Relationship between English learning motivation types and self-identity changes among Chinese students, (w:) „TESOL Quarterly” 41 (1), 133-155. 